Zeszyty Naukowe Szkoły Głównej Gospodarstwa Wiejskiego w Warszawie Problemy Rolnictwa Światowego tom 17 (XXXII), zeszyt 3, 2017: 154-165

DOI: 10.22630/PRS.2017.17.3.62

Karolina Jąder'

Uniwersytet Przyrodniczy w Poznaniu

\title{
Polski handel zagraniczny warzywami i ich przetworami w latach 2001-2015
}

\section{Polish Foreign Trade of Vegetables and their Preserves in 2001-2015}

\begin{abstract}
Synopsis. Celem opracowania było przedstawienie i ocena zmian w handlu zagranicznym warzywami i ich przetworami w latach 2001-2015. Zbadano wielkość oraz wartość eksportu i importu warzyw świeżych i ich przetworów oraz obliczono saldo handlu zagranicznego tymi produktami. W celu zobrazowania zmian analizowany okres podzielono na cztery podokresy. Przy zastosowaniu wskaźników dynamiki określono zmiany jakie zaszły w ilości i wartości eksportu i importu w kolejnych podokresach w stosunku do lat ich poprzedzających. Wydzielenie czterech podokresów umożliwiło również zdefiniowanie zmian w strukturze towarowej i geograficznej handlu zagranicznego Stwierdzono zwiększenie wielkości oraz wartości eksportu i importu, przy czym wyższy wzrost odnotowano w przypadku importu. W eksporcie szczególnie wzrosło znaczenie pomidorów oraz przetworów pomidorowych, natomiast w imporcie warzyw pozostałych. W strukturze geograficznej eksportu spadło znaczenie krajów Unii Europejskiej, natomiast wzrósł udział Wspólnoty Niepodległych Państw. W strukturze geograficznej importu odnotowano wzrost udziału krajów UE-15 oraz spadek krajów UE-12.
\end{abstract}

Slowa kluczowe: warzywa, przetwory warzywne, eksport, import

\begin{abstract}
The aim of the study was to present changes in the Polish foreign trade of vegetables and vegetable preserves in the years 2001-2015. The quantity and the value of the export and import of fresh vegetables and their preserves were researched. The balance of foreign trade was also calculated. To illustrate the changes the analyzed period was divided into four sub-periods, for which the dynamics of change were calculated. Within the sub-periods, exports and imports were presented in terms of their quantity, values and geographical structure. Results show that in the analyzed period the volume and value of exports and imports increased. The increase in imports was higher. Exports saw an especially high increase in tomatoes and tomato products, while imports saw increases in other vegetables. In the geographical structure of exports, the importance of EU countries dropped and the share of exports to the CIS states grew. In the geographical structure of imports, there was an increase from EU-15 countries and a decrease of from EU-12 countries.
\end{abstract}

Key words: vegetables, vegetables preserves, export, import, Poland, EU

\section{Wprowadzenie}

Powierzchnia upraw warzywniczych, wynosząca blisko 200 tys. ha, przy zbiorach które sięgają ponad $5 \mathrm{mln}$ ton rocznie, plasują nasz kraj w czołówce europejskich producentów warzyw. Polska zajmuje 4 miejsce, za zdecydowanie prowadzącymi w tym rankingu Hiszpanią, Włochami oraz niewiele wyprzedzającą ją Francją (Trajer, Dyngus, 2013). W Unii Europejskiej zajmujemy pierwsze miejsce w produkcji kapusty i marchwi, natomiast

${ }^{1}$ dr inż., Katedra Ekonomiki Przedsiębiorstw Agrobiznesu UP w Poznaniu, ul. Wojska Polskiego 28, 60-637 Poznań, e-mail: jader@up.poznan.pl 
trzecie w produkcji cebuli i ogórków. Warzywa przeznaczone są głównie na zaopatrzenie rynku wewnętrznego, na który trafi a około $90 \%$ towarowej produkcji, z tego ok. $70 \%$ sprzedawane jest na rynek warzyw świeżych a pozostała część do przetwórstwa. Pozostałe $10 \%$ trafia na eksport (Strategia krajowa..., 2010). Z przetworów warzywnych największe znaczenie mają mrożonki, a ich produkcja na poziomie ponad 600 tys. ton daje Polsce 2 pozycję w Europie. Struktura gatunkowa produkowanych warzyw jest zdecydowanie mniej zróżnicowana niż przeciętnie w Unii Europejskiej (Filipiak, 2014). Wynika to z uwarunkowań klimatycznych a także $z$ tradycji żywieniowych Polaków. Ze względu na umiarkowany klimat produkcja warzywnicza cechuje się dużą sezonowością, w związku z czym nawet wysoka produkcja krajowa niektórych warzyw musi być w pewnych okresach uzupełniana importem.

Celem niniejszego opracowania było przedstawienie i ocena zmian w handlu zagranicznym warzywami i ich przetworami w latach 2001-2015.

\section{Materiał i metodyka badań}

Analizę oparto na danych wtórnych pochodzących z publikacji Instytutu Ekonomiki Rolnictwa i Gospodarki Żywnościowej "Rynek owoców i warzyw" z lat 2002-2016.

Zbadano wielkość i wartość eksportu oraz importu, a także wyliczono saldo obrotów handlu zagranicznego. Określono również strukturę ilościową, wartościową i geograficzną eksportu oraz importu. Zakresem czasowym analiza objęła lata 2001-2015. W celu zobrazowania zmian jakie zaszły w badanym piętnastoleciu analizowany okres podzielono na cztery podokresy: lata 2001-2003, 2004-2007, 2008-2011 i 2012-2015. Wydzielenie pierwszego podokresu miało przede wszystkim na celu zbadanie zmian jakie zaszły w handlu zagranicznym warzywami i ich przetworami po akcesji Polski do Unii Europejskiej. Pozostałe 12 lat podzielono na 3 równe 4 letnie podokresy, co umożliwiło określenie zmian jakie zaszły w eksporcie i imporcie w latach poakcesyjnych. Obliczono średnie wartości importu i eksportu w ujęciu ilościowym i wartościowym, a przy zastosowaniu wskaźników dynamiki określono procentową zmianę w kolejnych podokresach $\mathrm{w}$ stosunku do lat ich poprzedzających. Wydzielenie czterech podokresów umożliwiło również zdefiniowanie zmian w strukturze towarowej i geograficznej handlu zagranicznego w analizowanym czasie.

\section{Zmiany wielkości, wartości i struktury eksportu warzyw i ich przetworów}

W latach 2001-2015 odnotowano wzrost wielkości i wartości eksportu zarówno warzyw świeżych, jak i ich przetworów. Średnia ilość sprzedawanych zagranicę warzyw świeżych zwiększyła się o 66,7\% z 294,7 tys. ton w latach 2001-2003 do 491,2 tys. ton w latach 20122015 (tab. 1). Najwyższy wzrost, wynoszący 47\% dotyczył czterech lat poakcesyjnych. Główną przyczyną tych zmian była akcesja Polski do Unii Europejskiej i związana z nią likwidacja barier celnych i technicznych oraz rosnący popyt na polskie produkty (Pawlak, 2014). W pozostałych wydzielonych podokresach eksport był już bardziej stabilny, aczkolwiek nadal charakteryzował się tendencją rosnącą. W jeszcze szybszym tempie niż wielkość eksportu zwiększała się jego wartość, gdyż odnotowano tu ponad czterokrotny wzrost z poziomu 60,1 do 252,6 mln euro. Podobnie jak ilość sprzedawanych warzyw, tak wartość, najbardziej (143,8\%) wzrosła w latach 2004-2007. 
W przypadku przetworów warzywnych wzrost wielkości eksportu był jeszcze wyższy. Porównując średnie wyniki w dwóch skrajnych wydzielonych podokresach sprzedaż wzrosła o $110,5 \%$ z $306,4 \mathrm{mln}$ euro do $645,1 \mathrm{mln}$ euro. Nieco niższy niż w przypadku warzyw świeżych, bo wynoszący $178,4 \%$, był natomiast wzrost wartości eksportu przetworów warzywnych. Także tutaj najwyższy wzrost odnotowano w latach 2004-2007.

W strukturze wielkości eksportu warzyw świeżych największe znaczenie miały cebula, pomidory i kapusta, stanowiąc średnio 34,2, 15,2\% i 14,6\% sprzedawanych zagranicę warzyw (tab. 2). W strukturze wartości eksportu dominowały już tylko dwa gatunki: pomidory, z udziałem $27,7 \%$ oraz cebula, której odsetek eksportu wynosił $25 \%$. W badanych latach znaczenie cebuli w eksporcie malało, natomiast pomidorów rosło. Udział cebuli spadł z 49\% w latach 2001-2003 do 24,4\% w ostatnim wydzielonym czteroleciu. Z wyjątkiem niewielkiego wzrostu w latach 2004-2007, w każdym następnym wydzielonym podokresie odnotowywano spadek sprzedaży zagranicznej cebuli. Przyczyną tych zmian była przede wszystkim powolna utrata konkurencyjności cenowej, w porównaniu z innymi liczącymi się eksporterami (Kraciński, 2014). Wzrost cen, doprowadził nawet do przekroczenia wartości osiąganych przez głównych konkurentów: Holandii i Hiszpanii (Zaremba, 2015). Dodatkowym czynnikiem był dynamiczny wzrost eksportu z krajów pozaeuropejskich, w tym głównie $\mathrm{z}$ Indii i Chin, których ceny $\mathrm{w}$ ofercie eksportowej są także niższe od proponowanych przez Polskę (Nosecka, 2014). Spadek udziału cebuli w strukturze był również wynikiem wzrostu sprzedaży zagranicznej innych warzyw, głównie takich jak: pomidory, papryka, kalafiory czy marchew. Szczególną uwagę należy zwrócić na dwa pierwsze z wymienionych gatunków. Porównując średnie wyniki z dwóch skrajnych podokresów ilość sprzedawanych pomidorów wzrosła o $315,2 \%$, natomiast wpływy z tej sprzedaży zwiększyły się ponad siedmiokrotnie. Poskutkowało to wzrostem udziału pomidorów w strukturze wielkości i wartości eksportu, odpowiednio o 12,1 i 11,8 pkt. proc. Główną przyczyną wzrostu ilości sprowadzanych pomidorów w latach poakcesyjnych było zniesienie stawek celnych w eksporcie do krajów UE-15. Utrzymanie wysokiej dynamiki wzrostu $\mathrm{W}$ kolejnych podokresach było przede wszystkim wynikiem rosnącego zapotrzebowania importowego większości krajów importerów na pomidory, a dotyczyło to przede wszystkim Rosji, ale też USA, Wielkiej Brytanii, Niemiec i Francji. Zwiększały się również dostawy na rynek zbytu czołowych eksporterów, tj. Hiszpanii, Turcji, Maroka oraz Chin i Jordanii. Rosnący popyt w większości krajów świata stwarzał szansę na zwiększanie eksportu przez mniej liczących się dostawców - głównie oferujących relatywnie niskie ceny eksportowe, w tym przez Polskę (Nosecka, 2014).

Jeżeli chodzi o paprykę warto podkreślić przede wszystkim wysoki wzrost uzyskiwanych wpływów ze sprzedaży, które zwiększyły się ponad siedemnastokrotnie. W ujęciu ilościowym eksport tego warzywa wzrósł ponad ośmiokrotnie. Szansą na rozwój polskiego eksportu papryki jest to, że w okresach intensywnego plonowania papryki, tzn. od połowy sierpnia przez cały wrzesień, brakuje jej u największego producenta, jakim jest Hiszpania. To stwarza możliwość sprzedaży dosyć dużych ilości tego warzywa na rynkach Europy Zachodniej (www.ho.haslo.pl). 
Tabela 1. Wielkość i wartość eksportu warzyw i ich przetworów

Table 1. Volume and value for exports of vegetables and their preserves

\begin{tabular}{|c|c|c|c|c|c|c|c|c|}
\hline \multirow{4}{*}{ Wyszczególnienie } & \multicolumn{4}{|c|}{ Średnio w latach } & \multicolumn{4}{|c|}{ Dynamika zmian } \\
\hline & $\begin{array}{l}2001- \\
2003\end{array}$ & $\begin{array}{l}2004- \\
2007\end{array}$ & $\begin{array}{l}2008- \\
2011\end{array}$ & $\begin{array}{l}2012- \\
2015\end{array}$ & $2004-2007 /$ & 2008-2012/ & 2012-2015/ & 2012-2015/ \\
\hline & \multirow{2}{*}{\multicolumn{4}{|c|}{ Wielkość eksportu (tys. ton) }} & 2001-2003 & 2004-2007 & $2008-2012$ & $2001-2003$ \\
\hline & & & & & $\begin{array}{c}2001- \\
2003=100\end{array}$ & $\begin{array}{c}2004- \\
2007=100\end{array}$ & $\begin{array}{c}2008- \\
2012=100\end{array}$ & $\begin{array}{c}2001- \\
2003=100\end{array}$ \\
\hline Cebula & 144,3 & 149,9 & 125,3 & 120,0 & 103,9 & 83,6 & 95,8 & 83,2 \\
\hline Kapusta biała i czerwona & 51,9 & 61,2 & 60,9 & 62,7 & 117,9 & 99,6 & 102,9 & 120,8 \\
\hline Inne warzywa kapustne & - & 44,9 & 52,1 & 68,2 & - & 116,0 & 130,9 & 151,8 \\
\hline Ogórki & 13,7 & 22,3 & 13,4 & 10,3 & 163,4 & 60,0 & 76,9 & 75,4 \\
\hline Marchew & 10,2 & 18,3 & 33,1 & 33,3 & 179,7 & 180,5 & 100,7 & 326,5 \\
\hline Kalafiory & 8,5 & 16,7 & 21,3 & 28,1 & 196,2 & 127,7 & 131,9 & 330,6 \\
\hline Pomidory & 23,9 & 61,7 & 79,4 & 99,4 & 257,7 & 128,7 & 125,2 & 415,2 \\
\hline Buraki i inne korzeniowe & 8,4 & 13,3 & 18,7 & 23,1 & 158,7 & 140,9 & 123,5 & 276,1 \\
\hline Papryka & 2,1 & 7,6 & 10,9 & 16,9 & 366,5 & 143,6 & 155,4 & 817,7 \\
\hline Pozostałe & 31,8 & 37,4 & 21,5 & 29,3 & 117,7 & 57,5 & 136,2 & 92,2 \\
\hline Razem warzywa świeże & 294,7 & 433,2 & 436,6 & 491,2 & 147,0 & 100,8 & 112,5 & 166,7 \\
\hline Mrożonki & 240,1 & 314,8 & 336,8 & 426,7 & 131,1 & 107,0 & 126,7 & 177,8 \\
\hline Mrożone przetwory gotowe & 1,8 & 7,8 & 12,7 & 16,8 & 424,1 & 163,0 & 132,1 & 913,6 \\
\hline Susze & 11,4 & 15,0 & 21,4 & 30,3 & 132,2 & 142,1 & 141,7 & 266,1 \\
\hline Marynaty & 13,2 & 31,0 & 33,3 & 43,5 & 235,3 & 107,4 & 130,7 & 330,4 \\
\hline Kwaszona kapusta & 18,9 & 13,8 & 10,5 & 11,9 & 73,0 & 75,9 & 113,3 & 62,9 \\
\hline Konserwy & 14,3 & 24,5 & 35,5 & 51,8 & 171,7 & 144,7 & 146,1 & 362,9 \\
\hline $\begin{array}{l}\text { Warzywa tymczasowo } \\
\text { zakonserwowane }\end{array}$ & 4,2 & 2,6 & 4,9 & 8,7 & 61,2 & 190,2 & 179,9 & 209,4 \\
\hline Przetwory pomidorowe & 2,6 & 14,6 & 35,0 & 55,5 & 559,6 & 240,5 & 158,5 & 2133,7 \\
\hline Razem przetwory warzywne & 306,4 & 424,0 & 489,9 & 645,1 & 138,4 & 115,5 & 131,7 & 210,5 \\
\hline \multicolumn{9}{|c|}{ Wartośc eksportu (mln euro) } \\
\hline Cebula & 22,3 & 37,6 & 40,2 & 42,2 & 168,7 & 106,7 & 105,1 & 189,2 \\
\hline Kapusta biała i czerwona & 4,5 & 7,4 & 13,1 & 12,1 & 162,1 & 177,6 & 92,7 & 266,9 \\
\hline Inne warzywa kapustne & - & 12,9 & 21,2 & 25,9 & - & 164,3 & 121,9 & 200,4 \\
\hline Ogórki & 4,5 & 9,0 & 7,4 & 8,4 & 200,9 & 82,2 & 113,6 & 187,5 \\
\hline Marchew & 1,2 & 2,8 & 6,2 & 9,1 & 227,0 & 219,6 & 148,4 & 739,9 \\
\hline Kalafiory & 2,0 & 5,4 & 9,5 & 16,3 & 275,8 & 174,2 & 172,0 & 826,3 \\
\hline Pomidory & 11,8 & 44,0 & 57,5 & 79,4 & 374,2 & 130,7 & 137,9 & 674,4 \\
\hline Buraki i inne korzeniowe & 5,2 & 3,0 & 6,0 & 9,0 & 57,1 & 203,4 & 149,6 & 173,7 \\
\hline Papryka & 0,9 & 6,1 & 8,4 & 15,8 & 703,8 & 137,7 & 188,4 & 1826,0 \\
\hline Pozostałe & 7,8 & 21,1 & 20,8 & 34,5 & 269,7 & 98,2 & 166,3 & 440,4 \\
\hline Razem warzywa świeże & 60,1 & 149,3 & 190,1 & 252,6 & 248,3 & 127,3 & 132,9 & 420,1 \\
\hline Mrożonki & 105,7 & 141,4 & 177,3 & 226,5 & 133,8 & 125,4 & 127,7 & 214,3 \\
\hline Mrożone przetwory gotowe & 1,3 & 5,4 & 10,5 & 12,9 & 424,3 & 194,4 & 123,4 & 1018,4 \\
\hline Susze & 17,8 & 25,7 & 34,3 & 47,5 & 144,8 & 133,1 & 138,5 & 267,1 \\
\hline Marynaty & 14,0 & 23,1 & 30,5 & 38,4 & 164,3 & 132,2 & 125,9 & 273,5 \\
\hline Kwaszona kapusta & 9,7 & 4,4 & 5,1 & 6,1 & 45,4 & 115,3 & 119,2 & 62,4 \\
\hline Konserwy & 3,3 & 18,9 & 37,2 & 54,7 & 577,0 & 197,3 & 146,9 & 1673,0 \\
\hline $\begin{array}{l}\text { Warzywa tymczasowo } \\
\text { zakonserwowane }\end{array}$ & 9,1 & 0,9 & 2,8 & 4,6 & 9,9 & 308,3 & 164,9 & 50,5 \\
\hline Przetwory pomidorowe & 1,0 & 12,7 & 35,1 & 60,0 & 1229,0 & 276,6 & 170,7 & 5804,0 \\
\hline Razem przetwory warzywne & 161,8 & 232,4 & 332,7 & 450,4 & 143,6 & 143,1 & 135,4 & 278,4 \\
\hline
\end{tabular}

Źródło: obliczenia własne na podstawie Rynek owoców..., 2002-2016. 


\section{K. Jaqder}

W analizowanym okresie odnotowano wzrost eksportu zdecydowanej większości warzyw świeżych. Wyjątek stanowiły wspomniana już cebula, ogórki oraz warzywa sklasyfikowane jako pozostałe. Spadek w przypadku tych warzyw, podobnie jak cebuli, był spowodowany wzrostem konkurencyjności cenowej państw pozaeuropejskich i wzrostem znaczenia dostaw z takich krajów jak Chiny, czy kraje WNP (Nosecka, 2014).

Tabela 2. Struktura eksportu warzyw i ich przetworów (\%)

Table. 2. Structure of exports for vegetables and their preserves (\%)

\begin{tabular}{|c|c|c|c|c|c|c|c|c|}
\hline \multirow{2}{*}{ Wyszczególnienie } & \multicolumn{4}{|c|}{$\begin{array}{l}\text { Struktura ilościowa } \\
\text { Średnio w latach }\end{array}$} & \multicolumn{4}{|c|}{$\begin{array}{c}\text { Struktura wartościowa } \\
\text { Średnio w latach }\end{array}$} \\
\hline & $\begin{array}{l}2001- \\
2003\end{array}$ & $\begin{array}{l}2004- \\
2007\end{array}$ & $\begin{array}{l}2008- \\
2011\end{array}$ & $\begin{array}{l}2012- \\
2015\end{array}$ & $\begin{array}{l}2001- \\
2003\end{array}$ & $\begin{array}{l}2004- \\
2007\end{array}$ & $\begin{array}{l}2008- \\
2011\end{array}$ & $\begin{array}{l}2012- \\
2015\end{array}$ \\
\hline Cebula & 49,0 & 34,6 & 28,7 & 24,4 & 37,1 & 25,2 & 21,1 & 16,7 \\
\hline Kapusta biała i czerwona & 17,6 & 14,1 & 14,0 & 12,8 & 7,5 & 4,9 & 6,9 & 4,8 \\
\hline Inne warzywa kapustne & 0,0 & 10,4 & 11,9 & 13,9 & 1,4 & 4,1 & 4,4 & 6,3 \\
\hline Ogórki & 4,6 & 5,2 & 3,1 & 2,1 & 7,4 & 6,0 & 3,9 & 3,3 \\
\hline Marchew & 3,5 & 4,2 & 7,6 & 6,8 & 2,1 & 1,9 & 3,2 & 3,6 \\
\hline Kalafiory & 2,9 & 3,8 & 4,9 & 5,7 & 3,3 & 3,6 & 5,0 & 6,4 \\
\hline Pomidory & 8,1 & 14,2 & 18,2 & 20,2 & 19,6 & 29,5 & 30,3 & 31,4 \\
\hline Buraki i inne korzeniowe & 2,8 & 3,1 & 4,3 & 4,7 & 8,6 & 2,0 & 3,2 & 3,6 \\
\hline Papryka & 0,7 & 1,7 & 2,5 & 3,4 & 0,0 & 8,6 & 11,2 & 10,2 \\
\hline Pozostałe & 10,8 & 8,6 & 4,9 & 6,0 & 13,0 & 14,1 & 10,9 & 13,7 \\
\hline Razem warzywa świeże & 100,0 & 100,0 & 100,0 & 100,0 & 100,0 & 100,0 & 100,0 & 100,0 \\
\hline Mrożonki & 78,4 & 74,2 & 68,7 & 66,1 & 65,3 & 60,8 & 53,3 & 50,3 \\
\hline Mrożone przetwory gotowe & 0,6 & 1,8 & 2,6 & 2,6 & 0,8 & 2,3 & 3,1 & 2,9 \\
\hline Susze & 3,7 & 3,5 & 4,4 & 4,7 & 11,0 & 11,1 & 10,3 & 10,5 \\
\hline Marynaty & 4,3 & 7,3 & 6,8 & 6,7 & 8,7 & 9,9 & 9,2 & 8,5 \\
\hline Kwaszona kapusta & 6,2 & 3,3 & 2,1 & 1,8 & 6,0 & 1,9 & 1,5 & 1,3 \\
\hline Konserwy & 4,7 & 5,8 & 7,2 & 8,0 & 2,0 & 8,1 & 11,2 & 12,1 \\
\hline $\begin{array}{l}\text { Warzywa tymczasowo } \\
\text { zakonserwowane }\end{array}$ & 1,4 & 0,6 & 1,0 & 1,4 & 5,6 & 0,4 & 0,8 & 1,0 \\
\hline Przetwory pomidorowe & 0,8 & 3,4 & 7,1 & 8,6 & 0,6 & 5,5 & 10,6 & 13,3 \\
\hline Razem przetwory warzywne & 100,0 & 100,0 & 100,0 & 100,0 & 100,0 & 100,0 & 100,0 & 100,0 \\
\hline
\end{tabular}

Źródło: jak w tab. 1.

W strukturze eksportu przetworów warzywnych dominowały mrożonki, stanowiąc średnio $71,9 \%$ sprzedawanych zagranicę przetworów. W strukturze wartości eksportu ich udział był nieco mniejszy i wynosił 57,4\%. 10,1\% wpływów ze sprzedaży zagranicznej przetworów warzywnych uzyskiwano z eksportu suszy, a $9,1 \%$ z eksportu marynat. Udział pozostałych grup w strukturze nie przekraczał $10 \%$.

W badanym okresie zwiększyła się ilość i wartość eksportu prawie wszystkich przetworów warzywnych. Rekordowy wzrost odnotowano jednak w przypadku przetworów pomidorowych, których zagraniczna sprzedaż, porównując dwa skrajne podokresy zwiększyła się z 2, 6 do 55,5 tys. ton, a biorąc pod uwagę wpływy z ich sprzedaży wzrost był jeszcze wyższy, bo sześćdziesięciokrotny. Wpływ na to miały głównie niższe ceny 
eksportowe keczupu i sosów pomidorowych w Polsce od tych oferowanych przez większość liczących się na świecie eksporterów. Wysokość tych cen wynika $\mathrm{z}$ wykorzystania w produkcji tańszego od wytwarzanego w Polsce importowanego koncentratu pomidorowego i relatywnie niskich kosztów na poziomie przetwórstwa (Nosecka, 2014). Wysoki wzrost dotyczył także gotowych przetworów mrożonych oraz konserw, w przypadku których wielkość eksportu wzrosła odpowiednio o 813,6\% i 262,9\%, a jego wartość aż o 918,4\% i $1573 \%$. Wzrost sprzedaży zagranicznej naszego głównego produktu eksportowego mrożonek nie był tak wysoki, gdyż wyniósł tylko 77,8\% w ujęciu ilościowym i 114,3\% w ujęciu wartościowym. Spowodowało to spadek jego znaczenia w strukturze wielkości i wartości eksportu, odpowiednio o 12,3 i 15 pkt. proc. Eksport mrożonek jest jednak nie zagrożony, a co więcej można przewidywać jego wzrost w kolejnych latach, ze względu na rosnące zapotrzebowanie na te produkty, głównie w krajach UE-13 (www.arr.gov.pl) oraz zmniejszającą się produkcję i podaż eksportową z Belgii, głównego producenta warzyw mrożonych w Europie (Nosecka, 2014).

\section{Zmiany wielkości, wartości i struktury importu warzyw i ich przetworów}

W analizowanym piętnastoleciu zwiększała się także ilość i wartość sprowadzanych do Polski warzyw i ich przetworów, przy czym wzrost był tutaj jeszcze wyższy niż w przypadku eksportu. Porównując średnie wyniki z lat 2001-2003 oraz 2012-2015 stwierdzono, że wielkość importu warzyw świeżych zwiększyła się o $165,3 \%$ ze 181,4 do 481,4 tys. ton, natomiast jego wartość wzrosła o $329,1 \%$ z poziomu 98,5 do 422,6 mln euro (tab. 3). W przypadku przetworów warzywnych był to wzrost rzędu 189,9 i $242 \%$ z poziomu 76,4 do 221,6 tys. ton oraz 65,9 do $225,3 \mathrm{ml}$ euro. Należy podkreślić, że najwyższą dynamikę wzrostu odnotowano jednak nie, jak w przypadku eksportu w latach poakcesyjnych, a w trzecim wydzielonym podokresie, tj. w latach 2008-2011.

W strukturze wielkości importu warzyw świeżych dominowały dwa gatunki: pomidory i cebula, stanowiąc około połowy sprowadzanych do Polski warzyw (tab. 4). Znaczenie pomidorów $\mathrm{w}$ analizowanych latach utrzymywało się na stabilnym poziomie, natomiast udział cebuli w strukturze zmniejszył się z 25,5 do 15,8\%. Import obydwu gatunków wzrastał, jednak dynamika zmian w przypadku pomidorów była wyższa. Na zwiększenie importu pomidorów wpływ miało przede wszystkim zniesienie stawek celnych po 1 maja 2004 roku w imporcie z krajów rozszerzonej Unii Europejskiej oraz zastosowanie niższego cła w imporcie z krajów trzecich (Nosecka, 2006). Dodatkowo pozytywną zmianą było większe ustabilizowanie rynku poprzez wyrównanie poziomu notowań cen $\mathrm{w}$ czasie $\mathrm{i}$ mniejsze wahania sezonowe (Trzęsowski, 2005). Wspomniany spadek znaczenia cebuli wynikał też z wysokiego wzrostu importu innych gatunków warzyw, takich jak kalafiory, ogórki, kapusta, sałata czy warzywa pozostałe. Na szczególne podkreślenie zasługuje ostatnia wymieniona grupa. Porównując dwa skrajne podokresy ilość sprowadzanych z zagranicy warzyw, sklasyfikowanych jako pozostałe zwiększyła się ponad sześciokrotnie z 9,8 do 61,9 tys. ton, a ich udział w strukturze wzrósł z 5,4 do 12,9\%. Jeszcze bardziej zwiększyło się ich znaczenie w strukturze wartości importu. Ich odsetek wzrósł tutaj o ponad 12 pkt. proc., co było wynikiem blisko piętnastokrotnego wzrostu wartości ich importu z poziomu 4,9 do $72,7 \mathrm{mln}$ euro. 


\section{0}

Tabela 3. Wielkość i wartość importu warzyw i ich przetworów

Table 3. Volume and value of imports for vegetables and their preserves

\begin{tabular}{|c|c|c|c|c|c|c|c|c|}
\hline \multirow{4}{*}{ Wyszczególnienie } & \multicolumn{4}{|c|}{ Średnio w latach } & \multicolumn{4}{|c|}{ Dynamika zmian } \\
\hline & $\begin{array}{l}2001- \\
2003\end{array}$ & $\begin{array}{l}2004- \\
2007\end{array}$ & $\begin{array}{l}2008- \\
2011\end{array}$ & $\begin{array}{l}2012- \\
2015\end{array}$ & $\begin{array}{l}2004- \\
2007 /\end{array}$ & $\begin{array}{l}2008- \\
2012 /\end{array}$ & $\begin{array}{l}2012- \\
2015 /\end{array}$ & $\begin{array}{l}2012- \\
2015 /\end{array}$ \\
\hline & \multirow{2}{*}{\multicolumn{4}{|c|}{ Wielkość importu (tys. ton) }} & $2001-2003$ & $2004-2007$ & 2008-2012 & 2001-2003 \\
\hline & & & & & $\begin{array}{c}2001- \\
2003=100\end{array}$ & $\begin{array}{c}2004- \\
2007=100\end{array}$ & $\begin{array}{c}2008- \\
2012=100\end{array}$ & $\begin{array}{c}2001- \\
2003=100\end{array}$ \\
\hline Cebula & 46,3 & 52,8 & 81,7 & 76,2 & 114,1 & 154,6 & 93,3 & 164,6 \\
\hline Kapusta biała i czerwona & 2,5 & 2,4 & 13,2 & 12,1 & 94,0 & 561,7 & 91,7 & 484,0 \\
\hline Ogórki & 9,0 & 18,9 & 40,8 & 45,6 & 210,0 & 216,0 & 111,7 & 506,7 \\
\hline Marchew & 17,8 & 25,1 & 39,5 & 28,4 & 141,3 & 157,3 & 71,8 & 159,6 \\
\hline Pomidory & 47,9 & 65,8 & 109,5 & 137,1 & 137,2 & 166,5 & 125,2 & 286,0 \\
\hline Papryka & 20,3 & 21,1 & 38,5 & 48,9 & 103,9 & 182,2 & 126,9 & 240,2 \\
\hline Czosnek & 11,6 & 7,5 & 6,5 & 6,4 & 64,8 & 86,7 & 98,5 & 55,3 \\
\hline Kalafiory & 3,5 & 6,3 & 14,5 & 22,7 & 179,0 & 228,5 & 156,7 & 641,0 \\
\hline Sałata, cykoria, endywia & 5,7 & 7,4 & 17,1 & 28,8 & 129,7 & 232,3 & 168,4 & 507,4 \\
\hline Chrzan & 2,7 & 3,3 & 3,1 & 3,9 & 121,9 & 93,8 & 127,9 & 146,3 \\
\hline Pory i inne cebulowe & 4,3 & 4,8 & 8,8 & 9,5 & 110,2 & 184,8 & 107,9 & 219,8 \\
\hline Pozostałe & 9,8 & 20,5 & 44,0 & 61,9 & 208,7 & 214,4 & 140,7 & 629,7 \\
\hline Razem warzywa & 181,4 & 235,8 & 417,1 & 481,4 & 130,0 & 176,9 & 115,4 & 265,3 \\
\hline Mrożonki & 12,6 & 27,1 & 40,7 & 45,6 & 214,9 & 150,1 & 112,1 & 361,5 \\
\hline Susze & 6,4 & 9,6 & 17,3 & 20,2 & 149,2 & 180,6 & 117,1 & 315,6 \\
\hline Marynaty & 6,9 & 9,3 & 16,8 & 15,1 & 134,7 & 181,1 & 90,3 & 220,3 \\
\hline Przetwory pomidorowe & 30,8 & 40,5 & 78,7 & 92,5 & 131,6 & 194,2 & 117,5 & 300,5 \\
\hline Konserwy warzywne & 18,4 & 27,8 & 45,4 & 45,3 & 150,8 & 163,3 & 99,8 & 245,8 \\
\hline Warzywa tymczasowo & 1,3 & 1,9 & 2,3 & 3,0 & 148,1 & 116,9 & 131,1 & 226,9 \\
\hline Razem przetwory & 76,4 & 116,1 & 201,0 & 221,6 & 151,9 & 173,1 & 110,3 & 289,9 \\
\hline \multicolumn{9}{|c|}{ Wartość importu (mln euro) } \\
\hline Cebula & 3,7 & 8,1 & 15,6 & 15,0 & 219,5 & 193,8 & 96,3 & 409,8 \\
\hline Kapusta biała i czerwona & 0,5 & 0,8 & 4,6 & 4,2 & 160,0 & 568,8 & 92,3 & 840,0 \\
\hline Ogórki & 7,0 & 16,0 & 32,0 & 37,1 & 229,3 & 200,2 & 116,1 & 532,9 \\
\hline Marchew & 2,9 & 6,0 & 12,1 & 10,7 & 209,3 & 201,7 & 88,2 & 372,4 \\
\hline Pomidory & 36,9 & 61,8 & 108,4 & 145,5 & 167,2 & 175,6 & 134,1 & 393,8 \\
\hline Papryka & 29,4 & 30,1 & 53,2 & 71,4 & 102,1 & 177,0 & 134,2 & 242,5 \\
\hline Czosnek & 4,6 & 6,8 & 8,9 & 9,6 & 146,8 & 130,5 & 107,6 & 206,1 \\
\hline Kalafiory & 1,7 & 4,6 & 12,6 & 19,8 & 262,5 & 277,5 & 156,8 & 1142,3 \\
\hline Sałata, cykoria, endywia & 3,9 & 6,3 & 16,8 & 28,8 & 160,2 & 265,9 & 171,6 & 730,9 \\
\hline Chrzan & 1,1 & 2,0 & 2,8 & 2,5 & 179,5 & 139,2 & 91,8 & 229,5 \\
\hline Pory i inne cebulowe & 1,9 & 2,9 & 6,0 & 5,5 & 152,7 & 211,4 & 91,3 & 294,6 \\
\hline Pozostałe & 4,9 & 16,1 & 40,9 & 72,7 & 329,8 & 254,8 & 177,6 & 1492,8 \\
\hline Razem warzywa & 98,5 & 161,2 & 313,8 & 422,6 & 163,6 & 194,7 & 134,7 & 429,1 \\
\hline Mrożonki & 8,0 & 20,1 & 32,3 & 37,4 & 250,6 & 161,0 & 116,0 & 467,8 \\
\hline Susze & 11,6 & 14,6 & 30,2 & 32,3 & 126,2 & 206,7 & 107,0 & 279,3 \\
\hline Marynaty & 4,7 & 6,8 & 14,7 & 15,9 & 142,6 & 218,1 & 107,6 & 334,9 \\
\hline Przetwory pomidorowe & 22,9 & 24,5 & 61,6 & 79,3 & 106,6 & 252,0 & 128,7 & 345,8 \\
\hline Konserwy warzywne & 17,6 & 27,2 & 45,8 & 57,3 & 154,3 & 168,5 & 125,0 & 325,0 \\
\hline $\begin{array}{l}\text { Warzywa tymczasowo } \\
\text { zakonserwowane }\end{array}$ & 1,0 & 1,4 & 1,7 & 3,1 & 137,5 & 123,6 & 182,4 & 310,0 \\
\hline Razem przetwory & 65,9 & 94,4 & 186,3 & 225,3 & 143,4 & 197,3 & 120,9 & 342,0 \\
\hline
\end{tabular}

Źródło: jak w tab. 1. 
Analizując strukturę importu w ujęciu wartościowym należy podkreślić, iż ponad 50\% wartości importowanych warzyw stanowiły pomidory i papryka. Podobnie jak w przypadku struktury wielkości importu udział pomidorów pozostawał w analizowanych latach na wyrównanym poziomie, natomiast znaczenie papryki, pomimo wzrostu jej importu spadało. W badanym piętnastoleciu wzrastał import wszystkich gatunków warzyw z wyjątkiem czosnku. Spadek ilości i wartości sprowadzanego czosnku był skutkiem integracji Polski z UE i konieczności przywozu w ramach administrowanego przez Komisję UE Kontyngentu taryfowego (Rynek owoców..., 2005). Kolejna przyczyną były obawy zdrowotne i w wyniku tego mniejsze zainteresowanie tańszym i mniej aromatycznym czosnkiem pochodzącym od największego eksportera na świecie - Chin (www.portalspozywczy.pl).

Tabela. 4. Struktura eksportu warzyw i ich przetworów (\%)

Table. 4. Structure of exports for vegetables and their preserves (\%)

\begin{tabular}{|c|c|c|c|c|c|c|c|c|}
\hline \multirow{2}{*}{ Wyszczególnienie } & \multicolumn{4}{|c|}{$\begin{array}{l}\text { Struktura ilościowa } \\
\text { Średnio w latach }\end{array}$} & \multicolumn{4}{|c|}{$\begin{array}{l}\text { Struktura wartościowa } \\
\text { Średnio w latach }\end{array}$} \\
\hline & $\begin{array}{l}2001- \\
2003\end{array}$ & $\begin{array}{l}2004- \\
2007\end{array}$ & $\begin{array}{l}2008- \\
2011\end{array}$ & $\begin{array}{l}2012- \\
2015\end{array}$ & $\begin{array}{l}2001- \\
2003\end{array}$ & $\begin{array}{l}2004- \\
2007\end{array}$ & $\begin{array}{l}2008- \\
2011\end{array}$ & $\begin{array}{l}2012- \\
2015\end{array}$ \\
\hline Cebula & 25,5 & 22,4 & 19,6 & 15,8 & 3,7 & 5,0 & 5,0 & 3,6 \\
\hline $\begin{array}{l}\text { Kapusta biała } \\
\text { i czerwona }\end{array}$ & 1,4 & 1,0 & 3,2 & 2,5 & 0,5 & 0,5 & 1,5 & 1,0 \\
\hline Ogórki & 5,0 & 8,0 & 9,8 & 9,5 & 7,1 & 9,9 & 10,2 & 8,8 \\
\hline Marchew & 9,8 & 10,6 & 9,5 & 5,9 & 2,9 & 3,7 & 3,9 & 2,5 \\
\hline Pomidory & 26,4 & 27,9 & 26,2 & 28,5 & 37,5 & 38,3 & 34,6 & 34,4 \\
\hline Papryka & 11,2 & 9,0 & 9,2 & 10,1 & 29,9 & 18,6 & 16,9 & 16,9 \\
\hline Czosnek & 6,4 & 3,2 & 1,6 & 1,3 & 4,7 & 4,2 & 2,8 & 2,3 \\
\hline Kalafiory & 1,9 & 2,7 & 3,5 & 4,7 & 1,8 & 2,8 & 4,0 & 4,7 \\
\hline $\begin{array}{l}\text { Sałata, cykoria, } \\
\text { endywia }\end{array}$ & 3,1 & 3,1 & 4,1 & 6,0 & 4,0 & 3,9 & 5,3 & 6,8 \\
\hline Chrzan & 1,5 & 1,4 & 0,7 & 0,8 & 1,1 & 1,2 & 0,9 & 0,6 \\
\hline Pory i inne cebulowe & 2,4 & 2,0 & 2,1 & 2,0 & 1,9 & 1,8 & 1,9 & 1,3 \\
\hline Pozostałe & 5,4 & 8,7 & 10,6 & 12,9 & 4,9 & 10,0 & 13,0 & 17,2 \\
\hline Razem warzywa & 100,0 & 100,0 & 100,0 & 100,0 & 100,0 & 100,0 & 100,0 & 100,0 \\
\hline Mrożonki & 16,6 & 23,3 & 20,2 & 20,6 & 12,1 & 21,2 & 17,3 & 16,6 \\
\hline Susze & 8,4 & 8,2 & 8,6 & 9,1 & 17,6 & 15,5 & 16,2 & 14,3 \\
\hline Marynaty & 9,0 & 8,0 & 8,3 & 6,8 & 7,2 & 7,1 & 7,9 & 7,0 \\
\hline $\begin{array}{l}\text { Przetwory } \\
\text { pomidorowe }\end{array}$ & 40,3 & 34,9 & 39,1 & 41,7 & 34,8 & 25,9 & 33,1 & 35,2 \\
\hline Konserwy warzywne & 24,1 & 23,9 & 22,6 & 20,4 & 26,8 & 28,8 & 24,6 & 25,4 \\
\hline $\begin{array}{l}\text { Warzywa tymczasowo } \\
\text { zakonserwowane }\end{array}$ & 1,7 & 1,7 & 1,1 & 1,3 & 1,5 & 1,5 & 0,9 & 1,4 \\
\hline Razem przetwory & 100,0 & 100,0 & 100,0 & 100,0 & 100,0 & 100,0 & 100,0 & 100,0 \\
\hline
\end{tabular}

Źródło: jak w tab. 1 .

W imporcie przetworów warzywnych największe znaczenie miały trzy grupy: przetwory pomidorowe, konserwy warzywne oraz mrożonki. Stanowiły one średnio, odpowiednio 39, 22,8 i 20,2\% sprowadzanych do Polski przetworów. W strukturze wartościowej ich łączny udział był nieco mniejszy, co było wynikiem większego udziału suszy, których odsetek wyniósł średnio 16,8\%. W latach 2001-2015 wzrastała ilość i wartość importu wszystkich przetworów warzywnych. Było to głównie efektem zmian w sposobie żywienia Polaków, coraz bardziej ukierunkowanym na spożywanie żywności przetworzonej 


\section{K. Jaqder}

(www.ierigz.waw.pl). Najwyższy wzrost odnotowano w przypadku importu mrożonek. Ilość sprowadzanych przetworów tej grupy zwiększyła się blisko trzykrotnie, natomiast wartości ponad czterokrotnie. Wyniki te spowodowały też kilku procentowy wzrost znaczenia mrożonek w strukturze importu.

\section{Saldo obrotów handlu zagranicznego warzywami i ich przetworami}

We wszystkich wydzielonych podokresach ilościowe saldo obrotów handlu zagranicznego warzywami świeżymi przyjmowało wartości dodatnie, natomiast w ujęciu wartościowym było ujemne (tab. 5). Porównując dwa skrajne podokresy, zarówno saldo ilościowe, jak i wartościowe uległo zmniejszeniu. W latach poakcesyjnych nastąpił co prawda wzrost różnicy eksportu i importu, jednak w kolejnych podokresach, zarówno ilość jak i wartość sprowadzanych z zagranicy warzyw zwiększała się w szybszym tempie niż ilość i wartość eksportowanych warzyw. Spowodowało to wyraźne zmniejszenie salda.

Tabela 5. Saldo obrotów handlu zagranicznego warzywami i ich przetworami

Table 5. Balance of foreign trade of vegetables and their preserves

\begin{tabular}{l|cccc}
\hline \multirow{2}{*}{ Wyszczególnienie } & \multicolumn{4}{c}{ Średnio w latach } \\
& $2001-2003$ & $2004-2007$ & $2008-2011$ & $2012-2015$ \\
\hline \multirow{2}{*}{ Warzywa świeże } & 113,3 & 197,4 & 19,5 & 9,9 \\
Przetwory warzywne & 216,8 & 307,9 & 289 & 423,5 \\
& \multicolumn{4}{c}{ tys. ton } \\
Warzywa świeże & $-38,4$ & $-11,9$ & $-123,7$ & -170 \\
Przetwory warzywne & 95,9 & 138 & 146,3 & 225,2 \\
\hline
\end{tabular}

Źródło: jak w tab. 1.

Zarówno ilościowe, jak i wartościowe saldo handlu zagranicznego przetworami warzywnymi w latach 2001-2015 było dodatnie i wzrastało. W ujęciu ilościowym różnica między eksportem a importem wzrosła z poziomu $216,8 \mathrm{w}$ pierwszym trzyleciu do 423,5 tys. ton w latach 2012-2015, natomiast w ujęciu wartościowym z 95,9 do 225,2 mln euro.

\section{Struktura geograficzna eksportu oraz importu warzyw i ich przetworów}

W latach 2001-2015 ponad połowa wpływów uzyskiwanych z eksportu warzyw i ich przetworów pochodziła ze sprzedaży do krajów UE-15, przy czym głównymi importerami naszych produktów były Niemcy, Wielka Brytania i Holandia (tab. 6). Ich udział w strukturze eksportu w poszczególnych podokresach był dość wyrównany, chociaż od roku 2011 można było zaobserwować nieznaczne jego zmniejszenie. Na drugim miejscu, ze średnim udziałem wynoszącym $22 \%$ znajdowały się nowe kraje członkowskie, a wśród nich najwięcej produktów warzywnictwa wysyłano do Czech, Słowacji, Litwy i Rumunii. Ich udział w strukturze geograficznej eksportu w latach poakcesyjnych jednak wyraźnie zmalał, z 26\% w latach 2001-2003 do 21\% w kolejnym czteroleciu. Spadek ten nie wynikał jednak ze 
zmniejszenia sprzedaży do tych krajów. Wpływ na to miał przede wszystkim bardziej dynamiczny wzrost eksportu do krajów WNP. Po roku 2003 sprzedaż do tych krajów, a zwłaszcza Rosji, Ukrainy i Białorusi, wyraźnie wzrosła, co spowodowało zwiększenie ich udziału w strukturze, z $11 \% \mathrm{w}$ pierwszym wydzielonym podokresie do $15 \%$ w latach 2004 2007. W kolejnych czteroletnich okresach ich znaczenie wzrastało, pomimo dwukrotnych zakazów importu z Polski owoców i warzyw. Wprowadzone przez Rosję w 2006 i 2014 roku embarga spowodowały okresowe spadki udziału krajów WNP w strukturze geograficznej eksportu. Zmniejszenie eksportu do tych państw było częściowo „rekompensowane” zwiększeniem sprzedaży zagranicznej do nowych krajów członkowskich (Rynek owoców..., 2015). Wpłynęło to na zwiększenie znaczenia tych krajów w strukturze w latach 2007 i 2008 oraz 2014 i 2015 . W badanym okresie zmniejszył się też udział wpływów uzyskiwanych ze sprzedaży do pozostałych krajów. Ich znaczenie spadło z $8 \%$ w dwóch pierwszych podokresach do 5\% w dwóch ostatnich.

Tabela 6. Struktura geograficzna eksportu i importu warzyw i ich przetworów (\%)

Table 6. Geographical structure of exports and imports of vegetables and their preserves $(\%)$

\begin{tabular}{|c|c|c|c|c|}
\hline \multirow{2}{*}{ Wyszczególnienie } & \multicolumn{4}{|c|}{ Średnio w latach } \\
\hline & $2001-2003$ & 2004-2007 & 2008-2011 & 2012-2015 \\
\hline & \multicolumn{4}{|c|}{ eksport } \\
\hline UE-15 & 55 & 55 & 53 & 51 \\
\hline UE-13 ${ }^{2}$ & 26 & 21 & 21 & 21 \\
\hline WNP & 11 & 16 & 21 & 23 \\
\hline \multirow[t]{2}{*}{ Pozostałe } & 8 & 8 & 5 & 5 \\
\hline & \multicolumn{4}{|c|}{ import } \\
\hline UE-15 & 64 & 74 & 76 & 79 \\
\hline UE-13 ${ }^{2}$ & 26 & 12 & 9 & 7 \\
\hline WNP & 0 & 0 & 0 & 1 \\
\hline Pozostałe & 10 & 14 & 15 & 13 \\
\hline
\end{tabular}

Źródło: jak w tab. 1 .

W strukturze geograficznej importu, podobnie jak w eksporcie największe znaczenie miały kraje UE-15, przy czym ich udział był tutaj jeszcze większy, gdyż wynosił średnio $73,2 \%$. Najwięcej produktów warzywnictwa sprowadzano z Hiszpanii, Holandii, Włoch i Niemiec. W badanym okresie znaczenie tych państw systematycznie wzrastało, a szczególne zwiększenie ich udziału przypadło na lata poakcesyjne. Porównując lata 2001-2003 i 2004-2007 odsetek importu z tych krajów wzrósł z 64 do 74\%. Na znaczeniu wyraźnie straciły natomiast kraje UE-12, których średni udział w całym piętnastoleciu wynosił 13,2\%. W latach 2004-2007 ich udział spadł o 14 pkt. proc. z 26 do $14 \%$. W kolejnych latach odnotowywano dalszy, sukcesywny spadek ich znaczenia. W analizowanym okresie nieznacznie wzrósł udział państw pozostałych, wśród których największymi dostawcami były Chiny, Maroko i Turcja. W polskim imporcie warzyw i ich przetworów bardzo niewielki udział miały kraje WNP.

${ }^{2}$ do 2012 r. UE-12. 


\section{K. Jaqder}

\section{Podsumowanie i wnioski}

W latach 2001-2015 odnotowano wzrost, zarówno wielkości, jak i wartości eksportu warzyw świeżych oraz ich przetworów. Porównując średnie wyniki z lat 2001-2003 oraz 2012-2015 ilość sprzedawanych zagranicę warzyw świeżych zwiększyła się o 66,4\%, natomiast ich wartość wzrosła aż o $320,1 \%$. W przypadku przetworów wzrost wielkości eksportu był jeszcze wyższy i wyniósł 110,5\%, natomiast wartość zwiększyła się nieco mniej, bo o $178,4 \%$.

W badanych latach największe znaczenie w eksporcie miały cebula i pomidory, które stanowiły około 50\% sprzedawanych zagranicę warzyw świeżych. W strukturze sprzedawanych zagranicę warzyw, udział pomidorów wzrastał, natomiast cebuli zmniejszał się. Odnotowano wzrost wielkości eksportu większości gatunków warzyw, przy czym najbardziej wzrosła sprzedaż papryki, pomidorów, kalafiorów i marchwi. Spadek odnotowano w przypadku cebuli i ogórków. W analizowanym okresie wzrosła natomiast wartość eksportu wszystkich warzyw.

W strukturze eksportu przetworów warzywnych dominowały mrożonki, stanowiące średnio ponad $70 \%$ sprzedawanych zagranicę przetworów, jednak ich znaczenie w kolejnych wydzielonych czteroletnich podokresach malało. W bardzo szybkim tempie zwiększał się natomiast eksport i tym samym udział głównie przetworów pomidorowych, konserw oraz mrożonych przetworów gotowych.

Jeszcze wyższy wzrost niż w przypadku eksportu odnotowano w imporcie warzyw $\mathrm{i}$ ich przetworów. Wielkość importu warzyw świeżych zwiększyła się o 165,3\%, a jego wartość o $329,1 \%$. Import przetworów warzywnych wzrósł o odpowiednio 189,9 i 242\%.

W strukturze wielkości importu warzyw świeżych największy udział miały podobnie jak w eksporcie pomidory i cebula, stanowiące prawie połowę kupowanych zagranicą warzyw. W ujęciu wartościowym dominowały natomiast pomidory oraz papryka. W analizowanym okresie zwiększył się import prawie wszystkich gatunków warzyw, a najwyższy wzrost odnotowano w przypadku warzyw sklasyfikowanych jako pozostałe, kalafiorów, sałaty oraz ogórków.

Z wszystkich przetworów warzywnych najwięcej sprowadzano do Polski przetworów pomidorowych, konserw oraz mrożonek. W przypadku tych grup odnotowano też najwyższy wzrost importu. W badanych latach wzrastała wielkość i wartość wszystkich grup przetworów.

Dynamika zmian w eksporcie i imporcie wpłynęła też na kształtowanie się salda handlu zagranicznego warzywami i ich przetworami. Różnica między eksportem a importem w ujęciu ilościowym była dodatnia, zarówno w przypadku obrotów warzywami świeżymi jak i przetworami. Wartościowe saldo było jednak już tylko dodatnie w przypadku przetworów. W przypadku warzyw świeżych import wzrastał w szybszym tempie niż eksport, co spowodowało systematyczny spadek salda zarówno w ujęciu ilościowym jak i wartościowym. Odwrotna sytuacja miała miejsce w przypadku przetworów warzywnych, gdzie różnica między eksportem a importem zwiększała się.

Około 75\% wpływów ze sprzedaży zagranicznej produktów warzywnictwa uzyskiwano z eksportu do państw Unii Europejskiej, przy czym największy, bo ponad 50\% udział miały kraje UE-15. Ich znaczenie, podobnie jak nowych państw członkowskich, w analizowanym okresie sukcesywnie zmniejszało się na korzyść krajów WNP. Ich udział w kolejnych podokresach wzrastał, nawet pomimo okresowych spadków spowodowanych wprowadzeniem zakazów przywozu z Polski owoców i warzyw wprowadzonych przez Rosję 
w latach 2006 i 2014. W imporcie udział krajów UE-15 był jeszcze wyższy i wynosił średnio blisko $75 \%$. W badanych latach ich odsetek $\mathrm{w}$ strukturze systematycznie wzrastał, a najbardziej w latach poakcesyjnych. Zwiększyło się także znaczenie krajów pozostałych, a spadał udział państw UE-13.

\section{Literatura}

Filipiak, T. (2014). Zmiany na rynku warzyw i w gospodarstwach warzywniczych w Polsce po integracji z Unią Europejską. Wyd. SGGW, Warszawa.

http://www.arr.gov.pl/data/400/biuletyn 173 nr11.pdf.

http://www.ho.haslo.pl?article.php?id=3092.

http://www.ierigz.waw.pl/.../18790_przemysł_spożywczy_makrootoczenie,_inwestycje,_ekspansja_zagraniczna. pdf.

http://www.portalspozywczy.pl/owoce-warzywa/wiadomosci/popyt-na-czosnek-rosnie-ale-produkcjaspada, 68204 1.html.

Kraciński, P. (2014). Przemiany na rynku cebuli w latach 1995-2012. Zeszyty Naukowe SGGW, Ekonomika i Organizacja Gospodarki Żywnościowej, 107, 143-154.

Nosecka, B. (2006). Import produktów rolno-spożywczych uznanych za wrażliwe. IERiGŻ-PIB, Warszawa.

Nosecka, B. (2014). Zewnętrzne uwarunkowania wzrostu eksportu owoców, warzyw i ich przetworów z Polski. Roczniki Naukowe Ekonomii Rolnictwa i Rozwoju Obszarów Wiejskich, 101(3), 133-144.

Pawlak, K. (2014). Zmiany w polskim handlu zagranicznym produktami rolno-spożywczymi po akcesji do Unii europejskiej. Zeszyty Naukowe SGGW Problemy Rolnictwa Światowego, 14(2), 170-184.

Rynek owoców i warzyw. Stan i perspektywy. (2002-2016). IERiGŻ-PIB, Warszawa, nr 20-49.

Strategia krajowa dla zrównoważonych programów operacyjnych organizacji producentów owoców i warzyw w Polsce na lata 2010-2013.2010: Dziennik Urzędowy Ministra Rolnictwa i Rozwoju Wsi, Warszawa.

Trajer, M., Dyngus, M. (2013). Krajowa produkcja, spożycie oraz promocja owoców i warzyw. Biuletyn Informacyjny, ARR, Warszawa.

Trzęsowski, M. (2005). Ceny pomidorów na rynku hurtowym w 2005 roku. Hasło Ogrodnicze, 12.

Zaremba, Ł. (2015). Produkcja i eksport cebuli z Polski na tle rynku Unii Europejskiej, Roczniki Naukowe SERiA, $17(5), 348-352$ 